\title{
A fluorescent antibody test in the diagnosis of farmer's lung
}

\author{
D. PARRATT AND J.A. PEEL
}

From the Department of Bacteriology and Immunology, Western Infirmary, Glasgow

SYNOPSIS A test for farmer's lung is described employing the indirect fluorescent antibody technique. The test compared very favourably with standard precipitin tests, detecting $88 \%$ of a series of positive cases, as opposed to $38 \%$ detected by a precipitin test. The fluorescent antibody test, in $\overline{0}$ addition, introduced some measure of quantitation of the serological response in the disease.

Farmer's lung is a form of pulmonary extrinsic allergic alveolitis due to the inhalation of antigenic material from mouldy hay. It has been shown that patients exhibiting the disease have serum precipitins to extracts of Micropolyspora faeni and Micromonospora vulgaris which are thermophilic actinomycetes occurring in mouldy hay (Pepys and Jenkins, 1965). The laboratory diagnosis of the disease has rested largely on the demonstration of such precipitins by Ouchterlony double-diffusion methods or by immunoelectrophoresis (Pepys and Jenkins, 1965). Latex agglutination (Murray, Pepys, and Brighton, 1967) and complement fixation (Public Health Laboratory Service, 1967) have been employed but have been shown to hold little advantage over the precipitin tests.

The purpose of this study was to determine whether a fluorescent antibody test would be of any value in the diagnosis of Farmer's lung.

\section{Materials and Methods}

An indirect method of fluorescent staining was used allowing the patient's serum antibodies to attach to the antigen ( $M$. faeni), the antibodies then being detected by a fluorescein-conjugated antihuman gamma-globulin.

\section{ANTIGEN}

The antigen used was $M$. faeni (CUB 58) which was prepared by a method of slide culture adapted from a method described by Riddell (1951). A petri dish containing $1 \%$ glucose agar was inoculated with a heavy suspension of the organism in saline. Excess liquid was removed and the surface of the medium allowed to dry. Cylindrical blocks were then cut Received for publication 17 August 1972.

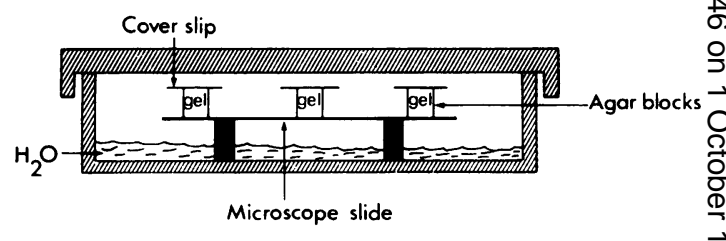

Fig. Diagram to illustrate method of slide culture.

from this medium using a no. 4 cork borer amds placed on microscope slides ( 3 in. $\times 1$ in.) as shown⿳亠二口犬 in Figure 1. Coverslips were placed on the uppero (inoculated) surface of the blocks, and sterile watero was added to each dish which contained the pre $\overrightarrow{\overrightarrow{0}}$ parations, to maintain humidity. The dishes were then incubated at $45^{\circ} \mathrm{C}$ for four days. After this time the coverslips were gently removed and lightly? heat fixed. A light circular growth of the organism was thus obtained in the centre of each coverslip? Storage of the specimens at $-20^{\circ} \mathrm{C}$ after fixing maintained the antigenicity for up to three months

SERUM

Twenty-five sera collected by Dr I. W. B. Grant? Respiratory Unit, Northern General Hospitalo Edinburgh, were investigated. These sera were collected during a survey of farmers in Scotland, of symptomatic diagnosis of the disease being accepted or rejected on the basis of enquiry into the presence or absence of bouts of the disease together witk evidence that exposure to mouldy vegetable produce had or had not occurred (Grant, Blyth, Wardropoc Gordon, Pearson, and Mair, 1972). The clinicad status pertaining to each specimen investigated was not known at the time of applying the fluorescenț antibody test. 
In addition, 20 normal sera received for investigation unconnected with Farmer's lung were tested to determine the response of such sera in the fluorescent antibody test.

All sera were inactivated at $56^{\circ} \mathrm{C}$ for 30 minutes before use in the test. They were used neat and at dilutions of 1 in 10,1 in 20,1 in 30, and 1 in 50 . Any sera showing positive reaction at a dilution of 1 in 50 were further diluted by doubling steps until a positive result was no longer obtained.

Sera not under investigation were stored at $-20^{\circ} \mathrm{C}$.

\section{CONJUGATED ANTIHUMAN GAMMA} GLOBULIN

This was prepared in our laboratory. Rabbit antihuman globulin was conjugated with fluorescein isothiocyanate according to standard methods (Nairn, 1969). Non-specific staining was removed by passage of the conjugate through a DEAE cellulose column. The same batch of conjugate was used throughout the series.

\section{PROCEDURE}

Patients' serum at various dilutions was dropped onto antigen specimens and allowed to react for 30 minutes at room temperature. The specimens were then washed with phosphate-buffered saline at $p \mathrm{H}$ $7 \cdot 1$ for 10 minutes. After this time the specimens were removed and the area around the central growth line was dried carefully. One drop of conjugate was then added to each specimen and allowed to react for 30 minutes at room temperature. After this period the specimens were washed with phosphatebuffered saline for 15 minutes, and then mounted in phosphate-buffered saline on microscope slides, the edges being sealed with nail varnish.

In addition to the sera under test certain controls were included with each test series. These were as follows: (1) specimen, untreated, mounted in phosphate-buffered saline; (2) specimen, treated with a normal serum, then antihuman globulin conjugate; (3) specimen, no serum added, antihuman globulin conjugate only; (4) specimen treated with serum from a known case of farmer's lung, then antihuman globulin conjugate.

If any controls reacted in unpredictable fashion the particular batch of tests to which it belonged was discarded and repeated. Specimens were examined using a Vickers Patholux microscope fitted with fluorescence attachment and employing a bright field condenser. For blue light ultraviolet illumination the primary filter was a BG $12 / 4 \mathrm{~mm}$ and the barrier filters $51 / 1.5 \mathrm{~mm}$ and GG $9 / 1.5 \mathrm{~mm}+$ clear glass $/ 1.5 \mathrm{~mm}$. For ultraviolet illumination the primary filter was a UG2/2 $\mathrm{mm}$ and the barrier filter GG $4 / 1.5 \mathrm{~mm}+$ Wratten $2 \mathrm{E}+$ clear glass $/ 1.5 \mathrm{~mm}$.
PRECIPITIN TESTS

After all sera had been examined by the fluorescent antibody test, precipitin tests were carried out against several extracts of $M$. faeni at varying concentrations according to the method of Pepys and Jenkins (1965). All sera were tested by this method on three separate occasions.

\section{Results}

Visualization of fluorescent staining was found to be easy using the antigen preparations prepared by slide culture although attempts to use smear preparations of the organism were disappointing, interpretation of positive from negative reactions being at times difficult. The slide culture specimens also had the advantage that it was possible to ensure complete coverage of the specimen with patients' serum and conjugate. A further advantage of the slide culture method is that it allows visualization of a single layer of organisms, free of clumping, and the development of spores along the mycelium is well seen. In cases where positive fluorescence was obtained, it was consistently observed that the spores were more actively fluorescent than the mycelium.

Fluorescence examination was found to be easier using blue-light illumination as opposed to ultraviolet light illumination, although the latter was satisfactory for examination of strongly positive specimens. $M$. faeni naturally emits a dull yellow autofluroescence when examined with blue light illumination, although it is rarely difficult to distinguish this from true fluorescence which appears bright apple green under the same conditions.

The results of the fluorescent antibody test were expressed on the basis of their titre, ie, the highest dilution of serum which gave positive fluorescence was taken as the endpoint for the test. Table I shows

\begin{tabular}{lll}
\hline No. of Sera & Precipitin Test & Fluorescence Titre \\
\hline 10 & Negative & 0 \\
7 & Negative & $1: 10$ \\
3 & Negative & $1: 20$ \\
\hline
\end{tabular}

Table I Tests on 20 'normal' sera

the reaction of the normal sera in the precipitin and fluorescent antibody tests. None of these normal sera showed positive fluorescence beyond a titre of 1 in 20 and all showed negative precipitin reactions. The titre level of 1 in 20 was then taken as the level of significance for all further tests, titres of 1 in 20 and below being regarded as negative, titres above 1 in 20 being regarded as significant. 
Table II shows the results of tests on the 25 unknown sera collected from farmers. Of these sera, 18 were subsequently considered to be from cases of farmer's lung, the remaining seven being regarded as clinically negative.

\begin{tabular}{|c|c|c|c|}
\hline Serum & $\begin{array}{l}\text { Precipitin } \\
\text { Results }\end{array}$ & $\begin{array}{l}\text { Fluorescence } \\
\text { Titre }\end{array}$ & Clinical Status \\
\hline $\begin{array}{l}4381 \\
4379 \\
4380 \\
4398 \\
4397 \\
4383 \\
4375 \\
4395 \\
4400 \\
4393 \\
7447 \\
7072 \\
7818 \\
7071 \\
6998 \\
6853 \\
7196 \\
7246 \\
7197 \\
7069 \\
7117 \\
7070 \\
6852 \\
6699 \\
7168\end{array}$ & $\begin{array}{l}\text { Positive } \\
\text { Negative } \\
\text { Negative } \\
\text { Positive } \\
\text { Positive } \\
\text { Negative } \\
\text { Positive } \\
\text { Positive } \\
\text { Positive } \\
\text { Positive } \\
\text { Negative } \\
\text { Negative } \\
\text { Negative } \\
\text { Negative } \\
\text { Negative } \\
\text { Negative } \\
\text { Negative } \\
\text { Negative } \\
\text { Negative } \\
\text { Negative } \\
\text { Negative } \\
\text { Negative } \\
\text { Negative } \\
\text { Negative } \\
\text { Negative }\end{array}$ & $\begin{array}{l}1: 100 \\
1: 50 \\
1: 50 \\
1: 200 \\
1: 400 \\
1: 20 \\
1: 100 \\
1: 1600 \\
1: 200 \\
1: 200 \\
1: 50 \\
1: 20 \\
1: 50 \\
1: 20 \\
1: 50 \\
1: 20 \\
1: 20 \\
1: 50 \\
1: 20 \\
1: 50 \\
1: 20 \\
1: 20 \\
1: 50 \\
1: 50 \\
1: 50\end{array}$ & $\begin{array}{l}\text { Positive } \\
\text { Positive } \\
\text { Positive } \\
\text { Positive } \\
\text { Positive } \\
\text { Positive } \\
\text { Positive } \\
\text { Positive } \\
\text { Positive } \\
\text { Positive } \\
\text { Positive } \\
\text { Negative } \\
\text { Positive } \\
\text { Negative } \\
\text { Positive } \\
\text { Positive } \\
\text { Negative } \\
\text { Positive } \\
\text { Negative } \\
\text { Negative } \\
\text { Negative } \\
\text { Negative } \\
\text { Positive } \\
\text { Positive } \\
\text { Positive }\end{array}$ \\
\hline
\end{tabular}

Table II Results of fluorescent antibody test and precipitin tests on serum from 25 farmers screened for farmer's lung

Of the 18 positive cases, $16(88 \%)$ were detected by the fluorescent antibody test and seven (38\%) showed positive precipitins.

In the seven cases regarded as clinically negative the precipitin test was negative in all (100\%) whereas the fluorescent antibody test was negative in six $(85 \%)$.

The fluorescent antibody titre of sera from positive cases showing positive reaction in the precipitin test was found to be 1 in 100 or greater in all cases, whereas sera from positive cases with negative precipitins were below 1 in 100 .

\section{Discussion}

The results of this short survey into the use of a fluorescent antibody technique in the diagnosis of farmer's lung indicate that the method compares favourably with a double diffusion precipitin test. The fluorescent antibody test detects all cases with positive precipitins and in addition some patients who have negative precipitins and yet suffer symptoms of the disease. The precipitin tests are invariably positive in the acute but not necessarily in other stages of the disease. In a group of patients at different stages of the disease the fluorescent antibody 0 test gave $88 \%$ positive as against $38 \%$ for the precipitin test. Hence in less severely affected patients or $\stackrel{0}{.}$ or in those who are recovering from the disease the $\Rightarrow$ precipitin test may not be positive, although the $\frac{\text { ? }}{?}$ patient has, as shown here, significant levels of cir-들 culating antibody to $M$. faeni, which is detectable by $\frac{\overline{0}}{\bar{\rho}}$. the fluorescent antibody test. In addition, the fluorescent antibody test provides some measure of $\stackrel{\mathbb{D}}{\Omega}$ quantitation difficult to achieve by other methods, which establishes a serological baseline for follow up $\vec{\circ}$ of the patient.

Attempts to utilize latex agglutination and com- $\vec{\omega}$ plement-fixation tests to obtain sensitive quantitation of responses in farmer's lung have been dis=-? appointing (Murray et al, 1967; Public Healthî Laboratory Service, 1967), the results providinglittle information that could not be gained by pre-io cipitin tests alone. Refinement of antigenic extracts $\stackrel{\circ}{+}$ used in such tests would no doubt increase theiro sensitivity but in the meantime a semi-quantitative, $\rightarrow$ sensitive test is urgently required, since changes ino antibody level in cases of farmer's lung have con- $\frac{0}{0}$ siderable practical and theoretical significance in ao disease which is presumed to be an example of an Arthus-type hypersensitivity.

The range of titre of sera showing positive pent cipitin reactions reported in this paper demonstrateso

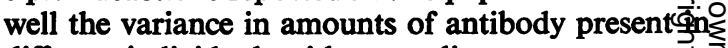
different individuals with acute disease.

The use of the fluorescent antibody test for surveying farming populations should be of con $\frac{0}{0}$ siderable value since it will enable detection of mild cases at a time when lung damage is minimal,, 3 allowing earlier curative and preventive measures to be more effective. Until purification and recognition of the various antigens involved in farmer's lung has. been accomplished, a highly accurate test for the? disease is unlikely to be developed but it is cons sidered that the test described here may well provide ${ }^{3}$. information of value in the diagnosis of this disease.

We wish to express our thanks to Professor R. $\mathbf{G}_{0}$ White, Department of Bacteriology and Immunology Western Infirmary, Glasgow, for his helpful advice We also extend our gratitude to Dr J. C. Gould Central Microbiological Laboratories, Edinburgh and Dr I. W. G. Grant, Respiratory Disease Unit, Northern General Hospital, Edinburgh, for kindly supplying some of the sera used in this investigation

References

Grant, I. W. B., Blyth, W., Wardrop, V.E., Gordon, R. M., Pearsonç J. C. G., and Mair, A. (1972). Prevalence of farmer's lung in Scotland: a pilot survey. Brit. med. J., 1, 530-534.

Murray, I. G., Pepys, J., and Brighton, W. D. (1967). The latex agglutination test in farmer's lung. Mth. Bull. Minist. Hlth Lab Serv., 26, 96-99. 
Nairn, R. C., Ed. (1969). Fluorescent Protein Tracing, 3rd ed. Livingstone, Edinburgh and London.

Pepys, J., and Jenkins, P. A. (1965). Precipitin (FLH) test in farmer's lung. Thorax, 20, 21-35.

Public Health Laboratory Service Working Party (1967). The com- plement fixation-test in farmer's lung. Mth. Bull. Minist. Hlth Lab. Serv., 26, 167-171.

Riddell, R. W. (1951). Laboratory diagnosis of common fungus infections. In Recent Advances in Clinical Pathology, 2nd ed., edited by S. C. Dyke, p. 77. Churchill, London. 